http://dx.doi.org/10.18778/0208-6107.32.04

\author{
Joanna Miksa \\ (iD) https://orcid.org/0000-0002-3517-7856 \\ Instutite of Philosophy \\ University of Lodz \\ jmalaxer@wp.pl
}

\title{
TRANSHUMANISM AS A CHALLENGE TO THE MEDICAL DOCTOR-PATIENT RELATION
}

\begin{abstract}
In this paper I undertake to analyze the way in which the arrival of HETs may influence the therapeutic relationship between the medical doctor and the patient. I begin with presenting he notion of transhumanism, insisting especially on the fact that some of the technologies that can be classified as HETs are already in use. As a result, the traditionally difficult task of defining health and a disease is becoming even more complicated. This circumstance poses the risk that medical doctors in their relationship with the patient, because of the possibilities offered by new technologies, will oscillate in their professional practice between helping the patient to recover and satisfying needs that are not justified by the considerations of health. I will try to show how the therapeutic relationship between the medical doctor and the patient may be transformed because of new technologies by using the example of IVF procedure applied to postmenopausal patients. In order to understand why the relationship between the medical doctors and their patients is so vulnerable in the context of transhumanism, I propose to re-analyze the most basic notions which help us understand the nature of the therapeutic relationship: the status of medicine as contrasted with technology, basic principles of medical ethics, the notion of a disease and an illness.
\end{abstract}

\section{Keywords:}

transhumanism, medical ethics, HET, IVF, human enhancement

\section{INTRODUCTORY REMARKS}

The central question that I want to discuss in my paper are the possible consequences of the advent of Human Enhancement Technologies (HETs) and the appearance of transhumanism for the profession of medical doctors and the nature of their therapeutic relationship with patients. Transhumanism is a notion that can be applied to a plethora of phenomena, some of them being mere projects or phantasies, the others being nevertheless practices which even if far from being numerous, have already entered the field of human experience. The 
advances in medicine and technology offer medical doctors new methods of treating the patients, but the very nature of those new inventions makes it difficult to decide up to which stage the relation between the patient and the medical doctor can still be called a therapeutic one. Modern medicine defines the relation between the medical doctor and the patient as the one which is founded on the principle of beneficience. The motivation of the profession of the medical doctor ever since medicine was born as a rationally defined field of human activity is to provide therapy, or put in other words, to make it possible for the patient to recover. In my paper, I want to concentrate on a way in which the advent of HETs is altering the nature of the relation in question, especially because of the fact that it alters the existing definitions of health and disease. Furthermore, it is not always easy to decide if using a given technology means bringing about the enhancement or recovery of the patient. For the profession of the medical doctor it means that, depending on the technological inventions that she or he uses, it is not always easy to tell the difference between a situation in which she or he stays in a therapeutic relationship which aims at the patient's recovery and a situation in which she or he simply enhances the patient. The latter involves improving the condition of the person in question, but the medical doctor is here only a provider of special services and the patient becomes a consumer of certain goods, the whole operation being a commercial transaction.

I will try to analyze the above-mentioned issues using the example of IVF practised on postmenopausal patients. The IVF procedure is not the first association that comes to one's mind once the subject of transhumanism is brought up. It has largely been accepted that IVF is a medical response to infertility, a medical condition which causes considerable suffering, and as such has a status of a disease recognized by WHO. I will not try to avoid the issue of the contentious nature of my choice of subject for discussion. On the contrary, I will insist on it. One of my aims in this paper is to show how transhumanism already influences the world of medicine and that it happens, among other things, because of the challenge that it poses to the definition of health. Using the case of IVF in the context of postmenopausal patients has, in my opinion, the advantage of being a real-life example of human enhancement that additionally presents terminological challenges which must be faced once transhumanism is discussed. The practice of making fertile - again or not - subjects who had crossed the biologically defined fertility limits is not as spectacular as the ambition to make people immortal, but has the unquestionable privilege of being a tangible experience.

\section{DEFINING TRANSHUMANISM}

Although transhumanism is unquestionably one of the most recurrent words in current bioethical discussions, it is still a reasonable decision to define it before starting a discussion on that subject. At this stage I propose to understand trans- 
humanism as a notion that embraces a number of ideas that have as their common denominator the conviction that due to technological progress it is possible to overcome the physical limits imposed on humans by their own nature. The term itself was coined by Julian Huxley, a biologist and brother of the author of The New Brave World, on the occasion of a conference entitled Knowledge, Morality and Destiny that he gave in 1951 and which was published in a review Psychiatry the same year. It became known to a wider public in 1957, when he published a book called New Bottles for New Wine in which he reemployed that term and developed on its meaning. ${ }^{1}$ If transhumanism was an idea cherished by few in the 50s, the situation has changed dramatically in the years that followed. On listening to one or the other contemporary enthusiast of the transhumanist movement, one can be tempted to believe that virtually all of the deficiencies of the human condition might cease to exist in an almost foreseeable future. The most daring of the exponents of the transhumanist movement do not hesitate to evoke immortality as one of the possible goals that could be achieved by contemporary scientists. One of the possible means to attain that dream could be transferring the sum of experiences, memories and thoughts of a chosen subject to an external support. Such a project is being financed by a Russian billionaire Dmitri Itskov, a founder of the 2045 Initiative, that is a net of scientists who work on technology that would make it possible to transfer the contents of a brain to a humanoid robot or hologram. ${ }^{2}$ Another possible solution to the problem of mortality that is considered by some transhumanism adherents is freezing human beings while they are still alive. As it is not legal, what is offered for the moment are the services of Alcor. Life Extension Foundation, which proposes freezing the body shortly after death - the whole of it or only brain, which is cheaper - so that a candidate to immortality can wait until medicine makes progress considerable enough so that she or he will be able to continue their earthly existence. $^{3}$

Taking into consideration the fact that transhumanism is a term that applies to so many and so diverse phenomena, it might be a reasonable idea to restrict myself here to introducing three of its aspects which will let me eventually analyze the central issue of this paper, which are the possible modifications of the relationship between medical doctors and their patients in the transhumanist era. Transhumanism can be namely explained through enumeration of the HETs in the first place, secondly as an ideology that motivates the actions of the transhumanism defenders and finally, one can refer to its philosophical analysis and definitions.

\footnotetext{
${ }^{1}$ Gilbert Hottois, Philosophie et idéologies trans/posthumanistes (Paris: Éditions Vrin, 2017), 35.

${ }^{2}$ See Jacques Testart and Agnès Rousseaux, Au péril de l'humain. Les promesses suicidaires des transhumanistes (Paris: Éditions du Seuil, 2018); Doug Bolton, "Russian billionaire Dmitry Itskov, seeks »immortality « by uploading his brain to a computer," Independent, March 14, 2016, https://www.independent.co.uk/news/science/dmitry-itskov-2045-initiative-immortality-brain-uplo ading-a6930416.html, accessed on October 2, 2018.

${ }^{3}$ See Testart and Rousseaux, Au péril de l'humain, 84-86.
} 


\section{TRANSHUMANISM AS FRUIT OF TECHNOLOGICAL PROGRESS}

As it has been said above, first of all, transhumanism can be defined through the technical advances which already make it possible for humans to transgress the biological limits of their nature. As such transhumanism is a series of phenomena which can be empirically observed. For the moment I will classify as HETs the technologies that people claiming that they are transhumanism activists consider to be of that kind. Still, I will underline the existence of cases that are difficult to classify. It is very important not to lose sight of the fact that even deciding which technology can be defined as belonging to the domain of human enhancement and which is a therapeutic one is not always obvious. That difficulty is not without effects on the status of a medical doctor once she or he enters into a therapeutic relationship with the patient. I will try to make that classification as simple as possible and I will not pretend to make my list of HETs exhaustive, but I think that starting from even so short and simplified a list of the transhumanist inventions draws our attention to the fact that transhumanism has become a subject of public concern precisely because it is becoming more and more a part of real life experience, even if the use of those technologies is restricted to a mi-nority of people. ${ }^{4}$

I propose to start the short presentation of HETs with the ones that improve the functioning of the human body. In this group there are bionic prosthesis and exoskeletons which were originally designed as a part of the rehabilitation process for handicapped patients. Conceived of for therapeutic use they may be qualified as HET, which was the case when one-legged runner Oscar Pistorius was excluded from the 2008 Olympics in Pekin, as it was decided that his prosthesis gives him an advantage over the other competitors. ${ }^{5}$ It was decided that the quality of the prosthesis is such that it does more than simply replace the articulation that had been lost, but it gives the runner capacities that are superior to the ones that an unenhanced body can have by nature. Moving further, it is not easy to say if there is a place for artificial organs on that list. An artificial heart replacing an ill heart only helps the patient to recover and as such is not an instance of human enhancement. But what should be said about prolonging human lifespan through a series of organ replacements? And what about replacing human organs by those extracted from animals or organs produced from stem cells?

HETs designed for the body were followed by those designed to enhance the functioning of the mind. We may speak about simple drugs making the functioning of the brain better, especially as far as memory and concentration are con-

\footnotetext{
${ }^{4}$ Making a list of HET's I followed their enumeration involved by Testart and Rousseaux in their book on transhumanism (Testart and Rousseaux, Au péril de l'humain, 17-115).

${ }^{5}$ Ibid., 18.
} 
cerned. An important group of HETs designed to improve the brain's performance is inspired by the technique of deep brain stimulation (DBS), designed by French neurosurgeon Alim Louis Benabid and used for 30 years now as a therapy for patients with Parkinson's disease. In recent years however successful attempts have been made at using that technique in healing other diseases, simply by placing the microelectrode in another part of the brain as in the case of Parkinson's disease. Professor Benabid's technique of DBS has been further used for treating obsessive-compulsive disorder and depression. As Testart and Rousseaux insist, in those cases what is influenced is personality and the mood. Professor Benabid is currently working in Clinatec, a research centre that he founded near his birthplace, Grenoble and which works on different types of DBS. Clinatec defines itself as a centre of medical research, and the potential of DBS for human enhancement is obvious, starting with improving human memory. ${ }^{6}$ There are as well discussions on using DBS in paraphilia patients, as the potential for changing human behaviour with the use of neurosurgery has been discovered owing to Benabid's invention. ${ }^{7}$

That is clearly a case which is not obvious to qualify. If we take into consideration paedophilia, which is a paraphilia classified as a psychiatric disorder, then using DBS as a cure is nothing more than medical therapy. In many other cases though it is just a technique changing behaviour without necessarily having a therapeutic character, showing how malleable human nature is. Still, that case shows that the technologies designed for therapeutic use can fairly easily change their status and become one of the HETs.

In this place the question may be posed if the birth of transhumanism was possible due to science or owing to technological progress. I believe that introducing that issue is important from the point of view of the attempt at defining transhumanism from the perspective of what has been actually achieved as far as HETs are concerned. The notion of science is not axiologically neutral, especially once we contrast it with that of technology. In the Western philosophical tradition science can be justified by the search for truth and as such, to some extent, has the characteristics of being autotelic. If we consider that problem from our contemporary perspective, it is important to say that it is furthermore rooted in the Enlightenment project. As opposed to that technology can be characterised as an enterprise serving pragmatically defined needs and considerations. Apart from that technology is indebted to science, the latter being superior by the virtue of the fact that it is armed with a method, which makes it possible to verify its claims. As opposed to that technology is a provider of tools which help to

\footnotetext{
${ }^{6}$ Ibid., 57-59.

${ }^{7}$ See Johannes Fuss, Matthias K. Auer, Sarah V. Biedermann, Peer Briken, Werner Hacke, "Deep brain stimulation to reduce sexual drive," Journal of Psychiatry and Neuroscience 40, no. 6 (2015), 429-31.
} 
resolve practical problems, but which can be used to achieve aims of all kinds, including morally dubious or unacceptable ones. In modernity the border between science and technology became blurred, not only the modern paradigm of science is not a contemplative one, as it was in the classical era, but because technology and its achievements have been possible due to science.

The difference between science and technology in the context of transhumanism can be discerned more clearly if we ask which institutions are mainly responsible for carrying out the research that led to the invention of HETs. Even if the technologies that can be classified as those which make human enhancement possible were born at universities, they have largely left Academia to thrive in the laboratories sponsored by the private sector. If it would be an exaggeration to say that on one hand we have universities as institutions which are purely science-oriented and on the other hand private laboratories which are technology-oriented, especially given the transformation that neoliberalism has imposed on the Academy, but it may still be said that commercial companies tend to be much more pragmatically oriented and that they do not carry out research simply because they want to quench their thirst for wisdom. Apart from that, which is rather obvious, they follow the logics of the market and are profit-driven. It is significant that nowadays human enhancement is a domain of activity of many start-ups set in Silicon Valley and constitute a favourite form of investment for many of its corporations. It is a widely known fact that it is Google Corporation and Jeff Bezos, the Amazon founder, who open the long list of subjects who invest in technologies which make transhumanism become a tangible reality. Private laboratories are also responsible for turning some of the technologies designed for therapeutic use into HETs, which transform human bodies without the motivation of making any kind of recovery possible. An example of such a technology may be a powered exoskeleton which was designed for the rehabilitation of handicapped patients as early as the turn of the 60s and 70s and which now might be used by the U.S. Army in order to improve soldiers' physical capacities. ${ }^{8}$

\section{TRANSHUMANISM AS AN IDEOLOGY}

Apart from being a part of a practice, transhumanism manifests itself as an ideology, that is a project or a series of projects of the future of human nature, which are not always followed by a critical or systematic reflexion. Transhu-

\footnotetext{
${ }^{8}$ See Todd South, "This Army unit will be the first to test an exoskeleton that lightens conbat load," Army Times, June 5, 2018, https://www.armytimes.com/news/your-army/2018/06/05/thisarmy-unit-will-be-first-to-test-an-exoskeleton-that-lightens-combat-load/.
} 
manism as an ideology embraces a plethora of attitudes which can differ significantly from one another, but it may be said that their common denominator is the conviction that technology is beneficial by its nature. As Jacques Testart, the French scientist who is responsible for the first birth due to IVF in France, wrote in his book on transhumanism with journalist Agnès Rousseaux: "To defend transhumanism means in the first place to be an unconditional and uncritical supporter of technophilia. The transhumanism supporters of all kinds defend as unavoidably beneficial, even if they are not directly related with enhancing humans, like for example transgenic plants or nuclear power. What seems to us to be a constant element in transhumanism of every sort is scientism, that is an ideology according to which the understanding of the world and its future depends on nothing but the progress of science and technologies." that the birth of many HETs was possible only as a result of acting against the protests and among the controversies formulated by the scientists themselves. A good example is the IVF procedure itself, which is not an HET itself, but which made many of them possible. Its father so to say, sir Robert Edwards, had to confront among other things the refusal of the Medical Research Council to found his research as well as the opposition of many of his colleagues.

The fact that transhumanism can be defined as a technology reflects an extremely important characteristic of that movement, which is the fact that to an important extent it functions outside Academia. Many of the leaders of the transhumanist movement are billionaires from the private sector who can afford sponsoring research on HETs. This means that a great deal of that research is carried out without the control of state administration, which normally includes opinions of ethics committees - an obvious routine in the case of research taking place at universities and in state-founded institutions. This means diminishing the role of universities, with its ethos that puts the quest after truth and democratic traditions, in the contemporary development of science. It does not mean necessarily that there is a rivalry between the Academy and private laboratories, but it does mean that universities are only one of the agents responsible for the progress of science. It is interesting to observe that the exponents of transhumanism are themselves divided on the understanding of the social function of science and the consequences of the development of HETs for the issue of social equality. On the one hand there are people who think that the notion of social equality is irrelevant in the context of transhumanism. The most prominent exponent of that attitude is Ray Kurzweil, a leader of the Singularity project. Interestingly enough, he started in Academia, that is as an MIT researcher, a position that he kept as he turned to the private sector when he got employed in 2012 by Microsoft, a company which cosponsors the Singularity project along with other multinationals. Kurzweil claims that the progress of science should follow ne-

\footnotetext{
${ }^{9}$ See Testart and Rousseaux, Au péril de l'humain, 133.
} 
oliberal logics and therefore the achievements of science do not have to be more equally shared than any other goods accessible on the market and subject to the principle of free exchange. ${ }^{10}$

The opposite position is defended by the founders of the World Transhumanist Association, which from 2008 is called Humanity+, the philosophers Nick Bostrom and David Pearce. In spite of the fact that Humanity + was founded by two philosophers, I will discuss its proposals in the section devoted to transhumanism as an ideology. It is because Humanity + is a nonprofit organisation, that is a movement that is open to anyone interested in the idea in question, it is not run by any university. It fights for the ethical use of technology, which among other things means making sure that all the people will have equal access to it. ${ }^{11}$ Defining transhumanism Bostrom says that: "Transhumanists view human nature as a work-in-progress, a half-baked beginning that we can learn to remold in desirable ways. Current humanity need not be the endpoint of evolution. Transhumanists hope that by responsible use of science, technology, and other rational means we shall eventually manage to become post-human, beings with vastly greater capacities than present human beings have." ${ }^{12}$ From that perspective technology should become a tool that will enhance human nature. What is interesting from the point of view of medical ethics is the fact that Bostrom defends among other things the use of genetic engineering, or more precisely germline engineering, that is introducing hereditary modifications to DNA. He claims that being healthy is something that is so obviously positive that it should be introduced by the means of HETs: "If we become healthier, we are personally better off and others are not any worse off. There may even be a positive externality of enhancing our own health. If we are less likely to contract a contagious disease, others benefit by being less likely to get infected by us. Being healthier, you may also contribute more to society and consume less of publicly funded healthcare." 13 The position defended by Bostrom shows how easy it may be to design a medicine that goes beyond restoring health and to reinterpret eventually the principle of beneficience on which medical ethics is founded in such a way that it will include the notion of enhancement. What I wanted to stress in that short section on transhumanism as ideology is the fact that the main visionaries of transhumanism participate in the debates over the vision of the society and profess well-precised views on the accessibility and status of HETs. As the HETs influence or will influence our wellbeing, it should be taken into consideration that the bulk of research on HETs is being carried out with the private

\footnotetext{
${ }^{10}$ Ibid., 126-128.

${ }^{11}$ See https://humanityplus.org/, accessed on October 6, 2018.

12 Nick Bostrom, "Human Genetic Enhancements: A Transhumanist Perspective," Journal of Value Inquiry 37, no. 4 (2003): 493-506.

${ }^{13}$ Ibid.
} 
money by people who believe that they are a good to be consumed and sold as any other service. Humanity + , set up by philosophers, is in that regard an interesting initiative, but does not have a decisive voice on the future of transhumanism. Understood as an ideology, apart from defending the thesis of the essential beneficial character of technology for human nature, transhumanism opens lots of space for the attitudes inspired by the logics of the free market.

\section{PHILOSOPHERS AND TRANSHUMANISM}

In the last resort, transhumanism is an object of philosophical reflexion. There is no use presenting in this paper the main philosophical positions which tend to appear systematically in the discussions on human enhancement. The disagreements between bio-conservatives and the supporters of the idea of human enhancement are too vast an issue to be included here. Let it suffice to say that first of all, the arguments put forward by philosophers are embedded in more traditional discussions on the functions of science and secondly, that they tend to follow the changes in the domain of human enhancement rather than put them forward. In spite of the enthusiasm that philosophy professed once confronted with the scientific progress at the dawn of modernity, the technology applied to the reality of the human body is so far welcomed with scepticism rather than with enthusiasm, the latter being limited to transhumanism movement activists and practitioners. To prove a rather sceptical approach of the philosophical academic world to the idea of transhumanism let it suffice to evoke the book written by Jürgen Habermas, The Future of Human Nature, which can be quoted as an example of a certain mistrust expressed by professional philosophers towards the idea of human enhancement. Another thinker who is at least not enthusiastic about transhumanism is Francis Fukuyama who in his book Our Posthuman Future. Consequences of the Biotechnology Revolution speaks in favour of a political debate over transhumanism and the opportunities it offers the humankind.

In the context of the philosophical dimension of transhumanism it might be useful to name the philosophical underpinnings of the transhumanist movement. They were listed in a concise and intelligent manner by a Belgian specialist in the field, Gilbert Hottois, whose analysis I will use in this place. In the first place Hottois speaks of the strong influence of the Anglo-Saxon tradition of utilitarianism, with its accent on hedonism on the transhumanist movement. It is significant, says Hottois, that one of the books written by David Pearce, the cofounder of World Transhumanist Association is called The Hedonistic Imperative. ${ }^{14}$ That utilitarian influence involves an empirical approach and hostility towards metaphysical thinking, which are strengthened by the influence of

\footnotetext{
${ }^{14}$ See Hottois, Philosophie et idéologies trans/posthumanistes, 61-63.
} 
pragmatism. ${ }^{15}$ As a consequence of that transhumanism is obviously an atheist movement, which is very difficult or even impossible to combine with religious thinking. It presupposes a clearly materialist vision of the world and human condition. As such transhumanism is an instance of secularisation as far as the approach to the notion of human nature is concerned. It is also an instance of scientism. ${ }^{16}$ The last of the characteristics may be an interesting one, given the growing popularity of movements questioning the authority of science.

\section{MEDICAL DOCTORS AND THE DISEASE/ILLNESS DISTINCTION IN THE CONTEXT OF HUMAN ENHANCEMENT}

It has been said in this paper that the arrival of the HETs along with the ideology of transhumanism is likely to transform the nature of the relation between the medical doctor and the patient. Before making explicit how and in what way a modification of that relation may come about, it is necessary to define what has constituted the essence of that relation until now. It may be safely said that the mission of the medical doctor in her or his relation with the patient is helping her or him to recover health. In this place there appears an element which is as difficult to define as it is crucial to understand the nature of a therapeutic relationship, and that element is health. Health has the characteristics of being a notion that cannot be defined with the exclusive use of terms from the field of natural sciences. It involves a subjective component that is provided by the agents living in a given society and in a given historical moment. The medical doctor and the patient might be seen as two candidates for defining what health is. The language, in the case of English, reflects that distinction by the presence of two terms which describe the lack of health, as it includes the terms such a disease and illness. It might be said that it is the medical doctor who is responsible for defining what a disease is a distortion of a normal functioning of an organism and that it is a patient who decides what an illness is that is what she or he perceives as suffering caused by a disease. The third term that I will not concentrate on in this paper would be sickness, that is a social dimension of a malaise.

The weight of the voice of the medical doctor and the patient as far as defining what health and a disease/illness are have never been equal. To explain this it is necessary to include further remarks on the character of the profession of a medical doctor. First of all, it is a profession which has a moral dimension. In

\footnotetext{
${ }^{15}$ Ibid., 64-69.

${ }^{16}$ Ibid., $71-81$.
} 
order to elucidate what is meant here I will resort to the analysis of the ethos of the medical doctor's profession proposed by Paweł Łuków. He insists on the fact that the medical profession belongs to a group of professions which need to be regulated not only by pragmatic rules defining what it means to carry out a task typical for that profession successfully, but it also needs principles which are of a normative nature. Medical doctors, claims Łuków, stand out along with advocates and teachers among others, by the nature of the good that they intend to bring about by carrying out their professional duties. The aim of the medical doctor is to bring about health, that is a good of special value from a social point of view. It means that no matter how one or the other member of a society defines health, it may be safely said that virtually every member of that society agrees that health and human life are important and that other important goods and values may be sought only once that fundamental good, which is health, is guaranteed. I other words, people may disagree on how we should live, but they do not question the conviction that health is a condition sine qua non of being able to follow any possible vision of a good life. ${ }^{17}$ Another factor that makes it necessary to impose normative rules on the profession of medical doctors is the fact that it cannot be always effectively controlled from the outside. The medical profession requires specialist knowledge which is not accessible to the patient and a certain margin of liberty in the process of decision making. Apart from that it is virtually impossible to control the motivation of the medical doctor and make sure that her or his motivation is the recovery of the patient and not considerations as for example of scientific interest or fame. It means that not everything may be regulated through legislation or rules dictated by medical knowledge. ${ }^{18}$ Providing the profession of medical doctors with moral principles, which are supposed to be internalised by the exponents of that profession in the process of education, shifts to a large extent the control over that professional group from the society at large to medical doctors themselves. The essence of those principles is making sure that the relation between a physician and a patient will serve to achieve the greatest good of the patient. ${ }^{19}$ It should be stressed here that the normative codes that are imposed on the medical profession serve the autonomy of that group and possibly make it more resistant once it is endangered for example by the process of commercialisation. I believe that it is precisely the moral dimension of the medical profession, an element that may seemingly be a fragile one, which may help it to overcome many of the dangers that transhumanism might bring about. The proper internalisation of moral norms by medical doctors, especially in the process of their education, may help them save

${ }^{17}$ See Paweł Łuków, Granice zgody: autonomia zasad i granica zgody pacjenta (Warszawa: Wydawnictwo Naukowe SCHOLAR, 2005), 29-36.

${ }^{18}$ Ibid., 39-44.

${ }^{19}$ Ibid., 42-43. 
the autonomy of their profession in the midst of commercialisation processes that transhumanism is entangled in.

If we say that the goal of the action undertaken by medical doctors is to work for the good of the patient, that is help her or him recover, it is still not clear how to define what health is. Traditionally, medical ethics was dominated by a paternalistic approach, according to which it is the medical doctor as a professional who decides what the good of the patient consists of. That situation has changed in the last 70 years in such a way, that today the medical doctor-patient relationship is ruled by the imperative of patient's autonomy. That demand is considered satisfied once the medical doctor obtains the patient's informed consent to carry out a medical treatment. That transformation reflects a dramatic shift in the medical doctor-patient relationship, the tendency being the increasing influence of the patient's will as far as the course of treatment is concerned. In other words, the contemporary paradigm would be one of patient autonomy. ${ }^{20}$ That tendency might have the effect of introducing new therapies with greater ease, if only they respond to needs manifested by the patients. In the democratic environment the patients armed with the doctrine of informed consent have a relatively big margin of action, at least compared to earlier times. The doctrine of informed consent may be understood and interpreted in various ways, but one of them says that the principle of patient autonomy is respected depending on the degree to which it is the patient who decides on the treatment that will finally be put into practice. ${ }^{21}$ In the case of HETs it makes it much easier for those technologies, I believe, to lose the status of a HET and gain the status of a therapeutic method because of the pressure coming from the bottom, that is from the patients. That would mean that medicine would be susceptible to developments of technology, and that the sheer existence of certain technological inventions would influence the concept of health.

It is not possible to discuss in this article all the ways in which the notion of autonomy in the context of medical ethics can be understood. It should be said, however, that it does not have to be understood as the patient becoming a medical doctor's equal partner in defining what should be achieved as a result of the treatment. That is not a reasonable option because of the difference in the knowledge that a medical doctor as a professional and the patient as a layman have. I believe that especially in the context defined by human enhancement an interesting proposal would be to interpret the principle of patient autonomy in Kantian terms, as it has been done by Luków. In that perspective the autonomy of the patient does not have to be measured by the extent to which it is the patient who decides what will happen to him during medical treatment. Instead, autonomy is understood as respect for a human person, which makes it obligatory for both the pa-

\footnotetext{
${ }^{20}$ Ibid., 126-129.

${ }^{21}$ Ibid., 12-14.
} 
tient and the medical doctor to mutually listen to each other. In other words, the perspective of the professional equipped with the knowledge and the perspective of the patient who suffers from an illness are meant to be considered as equally important. In the case of the medical doctor the respect for the patient's autonomy is put into practice if the doctor in question is capable of empathy and truthfulness in the relationship with the patient. ${ }^{22}$ That perspective has the advantage of freeing the medical doctor from the danger of reducing her of his role to following the patient's wishes. What is even more important in the context introduced by transhumanism, the situation in which the medical doctor refuses to satisfy the needs of the patient does not have to be interpreted as an instance of paternalism or not respecting the patient's autonomy.

It may be said furthermore that every medical intervention questions the biologically defined limits of human nature, as it is the illness and not medical intervention which constitutes a natural course of things. The demarcation line between human enhancement, which presupposes the overcoming of the biological limits of human condition, and the act of healing, which may be defined in this place as restoring the faculties diminished by a disease is not given once and for all but is negotiable and open to changes. Those changes are provoked to a great extent by the patients and their subjective understanding of what health is. As Dominique Folscheid and Jean-Jacques Wunenburger observe, when we speak about lack of health, an important aspect of that reality can be understood with the phenomenological approach which makes it possible to get access to the patient's inner experience. The suffering that the affected subject feels is an extremely important dimension of a situation in which we may speak of a loss of health. As the above-mentioned authors remark, what should be aimed at is "to explain what the disease consists in and to understand the sick. To concentrate on the sick person only poses a threat of losing from our sight the nature of a disease, but to concentrate exclusively on the objectified malaise brings about the risk that the medical doctor will turn into a tyrant who will treat the sick person as if she were a slave." ${ }^{23}$ The new situation the looms with the arrival of HETs is that it may be sometimes difficult to decide if what a person in question defines as an illness should be recognized as a disease or just as a need that does not need to be interpreted in medical terms.

\footnotetext{
${ }^{22}$ Ibid., 263-283.

${ }^{23}$ Dominique Folscheid and Jean-Jacques Wunenburger, "L'objet de la médicine," in Philosophie, éthique et droit de la médecine, ed. Dominique Folscheid, Brigitte Feuillet-Le Mintier, JeanFrançois Mattéi (Paris: Presses Universitaires de France, 1997), 135.
} 


\section{MEDICINE BETWEEN SCIENCE AND TECHNOLOGY}

The challenges medicine and medical ethics have to face in response to the brave new possibilities offered by HETs may be, as I am convinced, further understood if we go back to the beginnings of medicine as a rational enterprise. By doing so I will follow the way of thinking proposed by Dominique Folscheid, who posed a question of the main objectives of medicine and its status as a science. The birth of medicine, which meant freeing the healing procedures from religious and magical thinking, made it vulnerable to a rational critique. Once the medical doctor ceased to be a mediator between humans and gods, his actions could be described with the use of rationally coined terms. The fact that healing could no longer be described as a transfer of divine power to the human subject and started to be a result of human action translated itself immediately into the need of classifying medicine among all the possible types of knowledge. It was decided that medicine is a tekne - that is an art - and as such is different from sophia. Its basic characteristics are the fact that at the centre of its interest is the individual.

We may evoke here the famous Aristotle passage from the first book of Metaphysics, which reads: "With a view to action experience seems in no respect inferior to art, and men of experience succeed even better than those who have theory without experience. (The reason is that experience is knowledge of individuals, art of universals, and actions and productions are all concerned with the individual; for the physician does not cure man, except in an incidental way, but Callias or Socrates, or some other called by such individual name, who happens to be a man. If, then, a man has a theory without the experience, and recognizes the universal but does not know the individual included in this, he will often fail to cure, for it is the individual that is to be cured)." 24 Interestingly enough, modern medicine did not lose that characteristic of being a field of human rational activity which nevertheless cannot be simply qualified as science. In this context it is interesting to evoke the figure of René Descartes, for whom the status of the human body was a central issue. As Folscheid observes, it is a too common mistake to reduce Cartesian reflexion on the reality of human corporeality to the statement that the human body is defined as matter and that humans are a kind of mechanism. As Folscheid makes us remember, Descartes did not think that medicine can be classified as science in the full meaning of the term. ${ }^{25}$ In the Principles of Philosophy, published in 1644, Descartes seems to be optimistic about the status of medicine: "Thus, all Philosophy is like a tree, of which Metaphys-

\footnotetext{
${ }^{24}$ Aristotle, Metaphysics, trans. W. D. Ross, http://classics.mit.edu/Aristotle/metaphysics.1.i.html, accessed on October 6, 2018.

${ }^{25}$ See Dominique Folscheid, "La question de la médicalité", in Philosophie, éthique et droit de la médecine Philosophie, 114-115.
} 
ics is the root, Physics the trunk, and all the other sciences the branches that grow out of this trunk, which are reduced to the three principal, namely, Medicine, Mechanics and Ethics. ${ }^{26}$ However, in the letters written to Princess Elisabeth between 1643 and 1649 , he came to the conclusion that it is necessary to differentiate between medicine that can be called science, but which studies the body as a mechanism, and medicine that deals with individual living bodies. It belongs to the first type of medicine to study the body as a substance different from the mind, but what interests us is medicine that treats a body that is united with the mind, which is always a unique combination. That very special union can only be an object of an immediate intuition, says Descartes, a circumstance owing to which every adult person is her or his best doctor. He also says that the first type of medicine, that studies the body as a mechanism only, can be applied to animals as well as humans, which shows how empty-handed we are left if we insist that medicine should necessarily be a science. ${ }^{27}$ Without reaching conclusions as radical as Descartes did, the fact that even a thinker so often accused of reductionism in his reflection on human beings insisted so strongly on the individual dimension of medical treatment is significant. The relation between the medical doctor and the patient involves using the body of knowledge that may in theory be applicable to every human subject, but still, as trivial as it might sound, every patient is a unique case. For that reason, Folscheid proposes to understand contemporary medicine as a practice that is equipped with the achievements of modern science and technology, but at the same time has as its characteristic the fact that finally it is personalised, that is addressed to an unique individual. ${ }^{28}$

Obviously, the birth of medicine and its first or classical analysis do not have to necessarily apply in the context set up by modern medicine, supported by the findings of biochemistry and biophysics, equipped with ethical codes and enrichened by hundreds of years of experience. I claim nevertheless that the patient, who is not an expert and as such may happen to have the most absurd expectations, through her or his interaction with the medical doctor influences the shape of modern medicine in an important, even if difficult to measure, manner. Beyond any doubt, one of the factors that strengthens the position of the patient is the insistence on respecting the patient's will and vision of the treatment that she or he would like to receive, which manifests itself in the principle of in-

${ }^{26}$ René Descartes, The Principles of Philosophy, https://faculty.iiit.ac.in/ bipin/files/Dawkins/ New/Descartes $\% 252$ C\%20Rene $\% 20-\% 20$ The\%20Principles $\% 20$ of $\% 20$ Philosophy.pdf, accessed on October 6, 2018.

${ }^{27}$ Folscheid, "La question de la médicalité," 115.

${ }^{28}$ Ibid., 120-121. More precisely Folscheid defines medicine in the fragment I refer to in this place as une pratique soignante, personnalisèe, accompagnée de science et de technique (121). 
formed consent. Another factor is the fact the medicine and healthcare systems are not free from the pressures of the free market, which one again opens a way for the patients to introduce their understanding of health with a new force.

\section{INFERTILITY AND IVF PROCEDURE IN POSTMENOPAUSAL PATIENTS IN THE CONTEXT OF POSTHUMANISM}

The future of human enhancement will not be decided through an examination of the concept as such. As interesting as they may be, academic and nonacademic discussions on the transhumanist manifestoes are not a factor powerful enough to decide if that idea will thrive or perish. Apart from the big money invested in the field by human enhancement enthusiasts, the fundamental factor is the decisions taken by one of the medical doctors in the frame of their therapeutic relationships with their patients. What matters is on the one hand the needs and expectations expressed by the patients and what they subjectively perceive as a suffering. On the other hand, there is the response of medical doctors. That response may happen in two environments, the first one being the national healthcare system financed from taxes, varying in its characteristics from one country to another. The national healthcare systems have the characteristic of being defined by rather precise and often restrictive legislation. Medical services can nevertheless be obtained as well in the private sector. It is especially important in the case of therapies which for one or the other reason were not legislated upon. It may happen if a given technique is freshly accessible or if there is a political reason to avoid the public discussion on a given subject. That was the case of IVF in Poland, that has been carried out since 1987 with virtually no legal frame until as late as 2015 . Before that date the private clinics which offered IVF enjoyed a freedom of action on a scale unseen in other European countries. For the reasons discussed above, decisions taken by medical doctors as a result of negotiations with the patient - who has an important margin of liberty in defining how the notions of health and disease should be understood in her or his case - have a tremendous impact on the future of each of the HETs. I will try to show how easily a human enhancement may become a part of a therapeutic practice using the example of IVF carried out in postmenopausal patients.

The basic definition of IVF necessarily involves the information that it is a method designed to cure infertility. In its turn, infertility has been recognised as a medical condition by the World Health Organisation and it is defined, following the recommendations of International Committee for Monitoring Assisted Reproductive Technology (ICMART) from 2009, as "a disease of the reproductive system defined by the failure to achieve a clinical pregnancy after 
12 months or more of regular unprotected sexual intercourse." ${ }^{.29}$ In the definition nothing has been said about the causes of infertility. As a consequence, it will not be contrary to that definition to say that infertility that manifests itself after a woman has undergone menopause is a disease. On the other hand, though infertility after menopause is a natural change that is brought about by the ageing process. In that way it may be claimed that IVF applied to postmenopausal patients can be qualified as human enhancement, as it makes it possible for the patient to acquire physical capacities that are by nature out of their reach. The doubt can arise, that if we reduce ageing process to a series of losses of natural faculties, then maybe we may treat the process of becoming old itself as a disease that should be cured.$^{30}$ Loosing fertility after menopause is a limit imposed by human subjects by nature, for that reason I advocate the position the IVF procedure can be interpreted as an instance of human enhancement if it is applied to women that had undergone a menopause. I hope that example shows that telling a simply therapeutic technique from the one which is an instance of human enhancement is a contentious task. The facility with which the status ofa given technique may change is significant. Although human enhancement provokes many protests once it is discussed as an abstract term or a global project of the future of the humankind, it is easily accepted if it is being introduced into therapeutic practice by accepting new techniques of making the bodily existence more satisfying and congruent with the patient's vision of how our life should look like. In the case of IVF for postmenopausal patients we have nothing more than a new use of a recognized therapeutic method of treating infertility, which acquires the status of an enhancement - or at least there are grounds to interpret it as such.

When IVF came into being in the late 70s, it was directed to women in the reproductive age who were infertile. Initially though the medical problem that could be treated with IVF consisted in the fact that women affected by infertility were unable to conceive naturally even though they produced their own eggs. The technical progress transformed IVF in such a manner that it could be carried out in ever wider groups of possible patients when the technique of egg donation was invented. In 1983 a first successful IVF with egg donation took place in Australia. That meant that not only women who were unable to conceive naturally, but also women who were unable to produce their own eggs could become

\footnotetext{
${ }^{29}$ International Committee for Monitoring Assisted Reproductive Technology (ICMART) and the World Health Organization (WHO) revised glossary of ART terminology, 2009, accessed on October 6, 2018, http://www.who.int/reproductivehealth/publications/infertility/art_terminolo gy2.pdf.

${ }^{30}$ The information on IVF for postmenopausal women is obviously a subject present in the web, which is probably the first place in which potential patients seek information. On one of such pages with information on the chances of having a child after menopause we read what follows: "Can menopause be reversed? The short answer is no, but researchers are working on it", accessed on October 6, 2018, https://www.healthline.com/health/menopause/menopause-pregnancy\#ivf.
} 
pregnant. Technically, that opened a way to pregnancy for women after menopause, but the idea was thought at first to be ethically controversial because of the age of the prospective mothers - apart of the success rate for IVF the consideration that was typically raised was the life expectancy of the prospective mother and her general health conditions. ${ }^{31}$ Another change was introduced by the invention of the technique of oocyte crypreservation, which meant that a woman, depending on her life plans, could choose to freeze her eggs in case she decided to become mother later in her life. The first birth of a child born with the use of frozen oovocytes took place in 1986 in Singapore. ${ }^{32}$ Today the research is being carried out with the goal of obtaining eggs from nonreproductive cells. As two scholars, Daniela Cutas and Anna Smajdor comment: "If nonreproductive cells could be used successfully for the manufacture of in vitro derived eggs, menopause would no longer create the sort of infertility that it now does, and female fertility could be extended, in principle, indefinitely. Currently, the feasibility of postmenopausal motherhood is limited largely by its reliance on donated gametes. With the advent of in vitro derived eggs, this inbuilt limitation on the scope of postmenopausal motherhood would vanish." 33 If the number of postmenopausal women who became pregnant through the IVF procedure is raising, the reservations about that phenomena are reflected in the legislation considering the activities of national healthcare systems. Typically, women older than 42 are not eligible for the IVF procedure financed by the state, it can only be done in private clinics. It is the case of England and Wales, the NHS establishes that women under 40 are eligible for 3 cycles of IVF, women between 40 and 42 years to one cycle only, and patients older than that can only undergo the IVF procedure in private clinics. ${ }^{34}$ Those regulations follow the recommendations of National Institute for Health and Care Excellence (NICE). Here we have the perspective of the medical world, that is how the medical doctors and researchers understand what is good for the patient. In France IVF paid by the Securite Sociale is accessible to the age of 43 years. ${ }^{35}$ A more liberal approach among the medical doctors can be found in the United States, where the bulk of medical services is paid from private insurances. The North American Menopause Society recommends the age of 43 as the limit for the IVF procedure with the women's own oocytes and the age of 50 as the age limit of IVF carried out

\footnotetext{
${ }^{31}$ See Jennifer A. Parks, "A Closer Look at Reproductive Technology and Postmenopausal Motherhood," Canadian Medical Association Journal 154, no. 8 (1996): 1189-1191.

${ }^{32}$ See Chistopher Chen, "Pregnancy after human oocyte cryopreservation," The Lancet 327, no. 8486 (1986): 884-886.

${ }^{33}$ Daniela Cutas and Anna Smajdor, "Postmenopausal Motherhood Reloaded: Advanced Age and In Vitro Derived Gametes," Hypatia 30, no. 2 (2015): 386-402.

${ }^{34}$ See https://www.nhs.uk/conditions/ivf/availability/, accessed on October 6, 2018.

${ }^{35}$ See https://www.fiv.fr/fiv-apres-40ans/, accessed on October 6, 2018.
} 
with the donor's oocytes. ${ }^{36}$ The example of IVF for postmenopausal women not only offers an opportunity of showing how blurred the demarcation line separating therapy and enhancement is. It is also an instance of a possible conflict between what the medical doctors propose to understand as a therapeutic use of a given technology and how they understand what is good for the patient on the one hand, and how the patients themselves define what is beneficial for them. Some percentage of IVF procedures after menopause is carried out against recommendations of bodies gathering the medical doctors and researchers - that happens for example in the case of patients who have more than 50 years of age. It is significant also that all instances of IVF in postmenopausal women worldwide have been performed in private clinics, that is in the commercialised sector. It is not just a case of the market offering the possibility to satisfy basic needs of the patients where the state is not rich enough to sponsor them. It should be rather interpreted as an expression of the doubt whether IVF addressed to postmenopausal women is still a method that helps to recover or is it rather a medical service that makes it possible to satisfy a certain need. In the latter case what the medical doctor is doing is not really healing, it is rather helping someone shape their biography according to their wishes.

\section{HUMAN NATURE AND HUMAN ENHANCEMENT IN THE CONTEXT OF RISK SOCIETY}

Techniques of human enhancement are making their way into the reality of therapeutic practice through the decisions made and negotiated by the patients who contact the medical doctors. At this point I propose to interpret that phenomenon with the use of the theory of risk society formulated by Ulrich Beck. What will interest me most in this theory is the concept of reflexive modernity, which is characterised among other things by the necessity to compose one's own biography without being constrained to follow any given biographical pattern by the external factors in the way it was the case in the capitalist class society, let alone the feudal one. It is not necessarily because the postmodern world dwellers are so enthusiastic about being free from externally defined biographical patterns, but rather because the possible sources of constraints - social classes, national states, well-defined social groups with their codes of behaviour, are melting away. Beck calls that phenomenon individualisation and comments it in the following way: "Individualisation in this sense means that each person's biog-

\footnotetext{
${ }^{36}$ Jan L. Shifren and Margery L. S. Gass, "The North American Menopause Society Recommendations for Medical Care of Midlife Women," Menopause: The Journal of North Menopause Society 21, no. 10 (2014): 1-25, accessed on October 6, 2018, http://www.menopause.org/ docs/default-source/2014/nams-recomm-for-clinical-care.
} 
raphy is removed from given determinations and placed in his or her own hands, open and dependent on decisions. The proportion of life opportunities which are fundamentally closed to decision-making is decreasing and the proportion of a biography which is open and must be constructed personally is increasing. Individualisation of life situations and processes thus means that biographies become self-reflexive; socially prescribed biography is transformed into biography that is self-produced. Decisions on education, profession, job, place of residence, spouse, number of children and so forth, with all the secondary decisions implied, no longer can be, they must be made. ${ }^{, 37}$ At the time when Ulrich Beck wrote Risk Society, that is mid-1980, the human body might have still looked like a fairly stable element, even if the new medical technologies were already largely present and visible. Birth of Louise Brown in 1978, the world's first baby conceived through IVF was an obvious argument for claiming that the biological dimension of human condition will not be left untouched by the processes that make it necessary to decide individually about virtually all of the aspects of our biography. Forty years later, with the transhumanism gaining place as an ideology and the HETs leaving slowly, but constantly the realm of science fiction, it is obvious that at some point the biological dimension of human existence, that is our body, becomes a domain that will be defined more and more through human decisions. For the medical doctors it means a pressure exercised by the patients to do something more than to help them recover. As in the case of IVF in postmenopausal patients, the medical doctor's role is already being successfully defined as the one of a specialist who makes it possible to shape our biography more freely.

\section{CONCLUSION: THE PATIENT, THE MEDICAL DOCTOR, TRANSHUMANISM AND THE FREE MARKET}

The appearance of transhumanism constitutes one of those moments in which it is necessary to re-define concepts that might have seem to be so self-evident and fundamental that might have been safely taken for granted over a long span of time. First of all, the possible change of the position of a medical doctor in the relationship with a patient is a consequence of the challenge posed by transhumanism to the definition of health and disease. As those concepts are becoming more and more blurred, it is becoming increasingly probable that the function of the medical doctor will at some point oscillate between healing and administering technologies that cannot be justified or legitimised by the objective of restoring the health of the patient. The increasing accessibility of the new technologies which can be employed

${ }^{37}$ Ulrich Beck, Risk Society. Towards a New Modernity (London: Sage Publications, 1992), 135. 
with the objective of improving the functioning of human body beyond the limits defined by biology means that at some point using them or not will become an everyday decision - for the rich enough to have access to those achievements of modern technology.

An important factor that influences the evolution of the medical doctorpatient relationship in the context of transhumanism is the fact, that physicians and healthcare systems function in the commercialised environment. On one hand some of the laboratories responsible for research on human enhancement technologies are enterprises working in a free market. That is especially true of start-ups from the Silicon Valley, we have laboratories from Asia who are equally active in the field, but are not necessarily controlled by their respective states, we have finally European private laboratories. To some extent the enhancement technologies are goods for consumption that may become useful for therapeutic use, but do not need to be classified as such. Given the difficulties concerning drawing the dividing line between what is health and what is disease on the one hand, and what is therapy and what is enhancement on the other, it is hard to say the moment a new technology is designed if it will enter the field of medicine one day or it will be just a commercial product for private consumption. At this point it may be interesting to quote an opinion of Jacques Testart and Agnès Rousseaux who say that the arrival of transhumanism should be interpreted in the context of capitalism and the conviction or even phantasy typical of it which makes believe that every human need may be satisfied one day: "What is transhumanism? More than anything, it is an ideology of remplacement; a belief in the beneficial character of transhumanism succeeds the belief in the beneficial character of capitalism. The latter had promised the social progress and unlimited growth. Now it is foundering taking the army of unemployed with it, incapable of improving the situation of the population. What capitalism has to offer today is a challenge to everything it had made possible to achieve in the past: the social and economic gains, improving the living conditions... How is it possible not to see that it is the ideology of transhumanism which is replacing capitalism here by the fact that it promises long life and health without being any more credible in a world that is crumbling? And how is it possible not to see that the refuse to accept the finitude of the human being - its shortcomings and the fact of being mortal - is the same kind of thinking that is typical of capitalism which refuses to acknowledge the limits of our planet? And that is capitalism which, as if it was looking for its second chance, is supporting the enormous technological and financial investments in the development of transhumanism." 38 The profession of medical doctors is not free from the pressure of the free market and the logics of commercialisation brought about by capitalism. The definition of what the normal, healthy condition is as different from a disease is not free from the

${ }^{38}$ Testart and Rousseaux, Au péril de l'humain, 125. 
influence of capitalism, a system of production in which the concept of a need or an interest held by the subject - the potential consumer - plays a pivotal role. The patient who enters a medical centre can easily become a consumer of medical services, and the dividing line between the therapeutic and non-therapeutic use of medical technologies has never been less clear. For that reason, with the advent of transhumanism there is an important risk of medical doctor becoming a provider of the newest technologies and not any longer someone whose objective is to make the patient recover something as fundamental as health or, at times, to save someone's life.

The solution to that problem seems to be, as I believe, to a large extent in the hands of medical doctors. The future of their profession depends on their readiness to defend the autonomy and the moral dimension of that profession. The challenge posed by transhumanism shows how potentially dangerous might be reducing the principle of informed consent to the conviction that the medical doctor is there to simply follow the patient's will. It is unavoidably the education of the future medical doctors that may equip them with the consciousness of the normative dimension of their profession and prepare them for a difficult dialogue with the patient, in which the autonomy of the latter will be respected, but at the same time the place for a professional perspective will be guaranteed. That approach - which is not easy as its success depends greatly on the willingness of both sides of the therapeutic relation to participate in public, open debates on the definition of health and the social function of medicine and medical doctors - is obviously recommendable only until the moment in which a given society as a whole decides to become a member of the Humanity + association, thus deciding that human enhancement is a good as fundamental as health is in the currently valid medical ethics. An option that cannot be a priori excluded.

\section{BIBLIOGRAPHY}

Books and articles

Aristotle. Metaphysics, translated by W. D. Ross. http://classics.mit.edu/Aristotle/metaphysics.1.i.html. Beck, Ulrich. The Risk Society. Towards a New Modernity. London: Sage Publications, 1992.

Bostrom, Nick. "Human Genetic Enhancements: A Transhumanist Perspective." Journal of Value Inquiry 37, no. 4 (2003): 493-506. https://nickbostrom.com/ethics/genetic.html.

Chen, Christopher. "Pregnancy after human oocyte cryopreservation." The Lancet 327, no. 8486 (1986): 884-886.

Cutas, Daniela, and Anna Smajdor. "Postmenopausal Motherhood Reloaded: Advanced Age and In Vitro Derived Gametes." Hypatia 30, no. 2 (2015): 386-402. https://www.ncbi.nlm.nih. gov/pmc/articles/PMC4461075/.

Descartes, René. The Principles of Philosophy. https://faculty.iiit.ac.in/ bipin/files/Dawkins/ New/Descartes\%252C\%20Rene\%20-\%20The\%20Principles\%20of\%20Philosophy.pdf. 
Folscheid, Dominique. La question de la médicalite. In Philosophie, èthique et droit de la médicine, edited by Dominique Folscheid, Brigitte Feuillet-Le Mintier, Jean-François Mattéi, 111-121. Paris: Presses Universitaires de France, 1997.

Folscheid, Dominique, and Jean-Jacques Wunenburger. L'objet de la médicine. In Philosophie, èthique et droit de la médicine, edited by Dominique Folscheid, Brigitte Feuillet-Le Mintier, Jean-François Mattéi, 132-138. Paris: Presses Universitaires de France, 1997.

Fukuyama, Francis. Our Posthuman Future. Consequences of the Biotechnology Revolution. New York: Farrar, Straus, and Giroux, 2002.

Fuss, Johaness, Matthias K. Auer, Sarah V. Biedermann, Peer Briken, and Werner Hacke. "Deep brain stimulation to reduce sexual drive." Journal of Psychiatry and Neuroscience 40, no. 6 (2015): 429-31.

Habermas, Jürgen. The Future of Human Nature. Cambridge, U.K.: Polity Press, in association with Blackwell Publishing, 2003.

Hottois, Gilbert. Philosophie et idéologies trans/posthumanistes. Paris: Éditions Vrin, 2017.

Łuków, Paweł. Granice zgody: autonomia zasad i granica zgody pacjenta. Warszawa: Wydawnictwo Naukowe SCHOLAR, 2005.

Parks, Jennifer A. "A Closer Look at Reproductive Technology and Postmenopausal Motherhood." Canadian Medical Association Journal 154, no. 8 (1996): 1189-1191.

Shifren, Jan L., and Margery L. S. Gass. "The North American Menopause Society Recommendations for Medical Care of Midlife Women." Menopause: The Journal of North Menopause Society 21, no. 10 (2014): 1-25.

Testart, Jacques, Rousseaux Agnès. Au péril de l'humain. Les promesses suicidaires des transhumanistes. Paris: Éditions du Seuil, 2018.

\section{Press articles and web pages}

Bolton, Doug. "Russian billionaire Dmitry Itskov seeks »immortality« by uploading his brain to a computer." Independent, March 14, 2016, https://www.independent.co.uk/news/science/dmitry-itskov-2045-initiative-immortality-brain-uploading-a6930416.html

International Committee for Monitoring Assisted Reproductive Technology (ICMART) and the World Health Organization (WHO) revised glossary of ART terminology, 2009, http://www.who.int/reproductivehealth/publications/infertility/art_terminology2.pdf

South, Todd. "This Army unit will be the first to test an exoskeleton that lightens combat load," Army Times, June 5, 2018, https://www.armytimes.com/news/your-army/2018/06/05/thisarmy-unit-will-be-first-to-test-an-exoskeleton-that-lightens-combat-load/

https://humanityplus.org/

https://www.fiv.fr/fiv-apres-40ans/

https://www.healthline.com/health/menopause/menopause-pregnancy\#ivf

https://www.nhs.uk/conditions/ivf/availability 